\title{
Análise ambiental de fragmentos florestais em assentamentos rurais
}

\author{
Stela Maris Alves ASCENÇO
}

Dissertação de Mestrado: Curso de Mestrado em Geografia - UFPR

Data da defesa: 19 dez. 2003

Banca:

Everton Passo (orientador)
Luiz Eduardo Mantovani
Sony Cortese Caneparo

RESUMO

O processo de Reforma Agrária constitui-se em um agente transformador e ao mesmo tempo criador de espaços diferenciados, já que está associado às formas de apropriação e exploração da superfície terrestre. Dessa forma, os assentamentos rurais, produtos desse processo de transformação, tornam-se objetos de estudos da Geografia. Por causa das rápidas e inevitáveis transformações no uso da terra ocorridas nos assentamentos, que conduzem à fragmentação e até à supressão da vegetação natural, o objetivo da presente pesquisa consistiu em identificar e caracterizar ambientalmente os fragmentos florestais de ocorrência natural em áreas de assentamentos rurais, mais especificamente no Projeto de Assentamento Ireno Alves dos Santos, situado nos Municípios de Rio Bonito do Iguaçu e Nova Laranjeiras - PR, no período de 1996 a 2002; tais fragmentos são remanescentes da Floresta Ombrófila Mista e Floresta Estacional Semidecidual, cuja manutenção tornou-se bastante delicada, uma vez que deixaram de fazer parte de uma área florestada maior e passaram a ficar "ilhadas", cercadas por áreas agrícolas, desencadeando diversas alterações ambientais (efeitos de borda). O objetivo proposto foi atendido mediante a aplicação de metodologia para a identificação e manejo de fragmentos de áreas naturais proposta por PIRES et al. (1998). As tarefas necessárias ao desenvolvimento da metodologia foram operacionalizadas a partir de técnicas de Geoprocessamento e Sensoriamento Remoto, que permitiram a elaboração de mapas temáticos digitais representando a evolução da fragmentação florestal; ao final, foi gerado o mapasíntese da espacialização dos fragmentos florestais. Algumas hipóteses procuraram explicar as causas para as alterações verificadas ao longo dos anos na área do assentamento, tais como: a instalação da empresa madeireira proprietária da área; a construção da Usina Hidrelétrica de Salto Santiago; a implantação do assentamento. A escolha do assentamento como objeto de estudo recaiu sobre as características da sua ocupação, já que a propriedade que lhe deu origem apresentava uma área de 83.000ha de terras, adquiridas em 1972 por uma empresa privada do ramo madeireiro para o desenvolvimento de atividades diversas. A propriedade teve sua área reduzida em 1980, por causa do alagamento de parte de suas terras que abrigavam áreas de matas nativas, em virtude da construção da Usina Hidrelétrica. A partir de 1996, a propriedade passou por outra grande transformação mediante a ocupação por cerca de 3.000 famílias de trabalhadores rurais integrantes do MST, que se instalaram às margens da rodovia que atravessa suas terras (BR-158), dando origem ao maior Projeto de Assentamento do Paraná, em área e em número de famílias. Com os resultados obtidos, espera-se ter contribuído para o entendimento das transformações ambientais ocorridas no espaço do assentamento, em especial em suas áreas florestadas, demonstrando a aplicabilidade da metodologia utilizada, o uso das geotecnologias e a sua importância como um elo entre diferentes ramos do conhecimento, bem como o posicionamento dos organismos responsáveis pela implantação de assentamentos rurais quanto à aplicação da legislação ambiental brasileira em assentamentos rurais. Além disso, ao se definirem as alterações ambientais no assentamento, pode-se contribuir para o planejamento e aplicação de técnicas de manejo ambiental, quando da implantação de futuros projetos de assentamentos rurais.

Palavras-chave:

Análise ambiental, fragmentos florestais, assentamentos. 